\title{
Population dynamics and bio-intensive management of sorghum midge, Contarinia sorghicola (Coquillett) in sorghum under southern Tamil Nadu
}

\author{
P. ANANDHI*, S. ELAMATHI AND B. ARTHI RANI
}

Agricultural Research Station (T.N.A.U.), KOVILPATTI (T.N.) INDIA (Email: elamathi_aaidu@yahoo.co.in; arthiagrimet@gmail.com)

\section{ARITCLE INFO}

Received : 31.01 .2017

Revised : 24.03 .2017

Accepted : 28.03 .2017

KEY WORDS :

Sorghum, Midge, Contarinia sorghicola; Survey, Population dynamics, Bio-intensive management

*Corresponding author: anandhi.aaidu@gmail.com

\begin{abstract}
Surveys on distribution of sorghum midge at southern region of Tamil Nadu during 2011 to 2014 indicated that, midge observed in all areas of three districts. Effect of abiotic factors on sorghum midge revealed that maximum, minimum temperature, wind velocity and sunshine were positive while maximum, minimum relative humidity and rainfall showed negative correlation. Among bio-intensive management strategies, Neem oil 3 per cent showed maximum reduction (63.36), minimum midge incidence/ 5 panicle (17.5) and maximum grain yield (2498 kg/ha) when compared to control $(244 \mathrm{~kg} / \mathrm{ha})$. The highest incremental cost benefit ratio (ICBR) obtained in Neem seed kernel extract (NSKE) 5 per cent (1:24.7) followed by Neem leaf extract 5 per cent (1:22.3) treated plots.

How to view point the article : Anandhi, P., Elamathi, S. and Arthi Rani, B. (2017). Population dynamics and bio-intensive management of sorghum midge, Contarinia sorghicola (Coquillett) in sorghum under southern Tamil Nadu. Internat. J. Plant Protec., 10(1) : 167-173, DOI : 10.15740/ HAS/IJPP/10.1/167-173.
\end{abstract}

